\title{
Pengaruh Kualitas Produk, Harga, dan Citra Merek terhadap Loyalitas Pelanggan Kosmetik Natural Nusantara di Gunungkidul
}

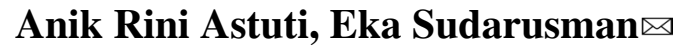 \\ Sekolah Tinggi Ilmu Manajemen YKPN Yogyakarta \\ e-mail: ekasud@yahoo.com
}

\begin{abstract}
The purpose of this study was to determine the effect of Product Quality, Price, and Brand Image on Customer Loyalty (Study on Customers of Natural Nusantara Cosmetics Product Users in Gunungkidul). The sampling technique has used a Non-Probability model used was the purposive sampling method. The sampling criteria in this study were that some customers of Natural Nusantara cosmetics users in Gunungkidul, had purchased Natural Nusantara cosmetic products at least twice. The sample in this study were 100 respondents, The data analysis method used Multiple Regression, $Y=15.163+0.212 X 1+0.433 X 2+(-0.006 X 3)$. The results showed that product quality and price had a positive and significant effects on customer loyalty of Nusantara Natural Cosmetics users in Gunungkidul. While brand image had a negative and had no significant effect on customer loyalty of users of Natural Nusantara Cosmetics products in Gunungkidul.
\end{abstract}

Keywords: product quality, price, brand image, customer loyalty

\begin{abstract}
Abstrak
Tujuan dari penelitian ini adalah untuk mengetahui pengaruh Kualitas Produk, Harga, dan Citra Merek terhadap Loyalitas Pelanggan (Studi pada Pelanggan Pengguna Produk Kosmetik Natural Nusantara di Gunungkidul). Teknik pengambilan sample dilakukan dengan menggunakan model Non-Probabilitas dengan metode purposive sampling. Kriteria pengambilan sampel dalam penelitian ini adalah sebagian pelanggan pengguna kosmetik Natural Nusantara di Gunungkidul, telah membeli produk kosmetik Natural Nusantara minimal dua kali pembelian. Sampel dalam penelitian ini sebanyak 100 responden. Metode analisis data menggunakan berganda, $\mathrm{Y}=$ $15,163+0,212 \mathrm{X} 1+0,433 \mathrm{X} 2+(-0,006 \mathrm{X} 3)$. Hasil penelitian menunjukan bahwa kualitas produk dan harga berpengaruh positif dan signifikan terhadap loyalitas pelanggan pengguna produk Kosmetik Natural Nusantara di Gunungkidul. Sementara Citra merek berpengaruh negatif dan tidak signifikan terhadap loyalitas pelanggan pengguna produk Kosmetik Natural Nusantara di Gunungkidul.
\end{abstract}

Kata kunci: kualitas produk, harga, citra merek, loyalitas pelanggan 


\section{PENDAHULUAN}

Kosmetik merupakan kebutuhan pokok bagi wanita di dunia. Di zaman modern saat ini setiap orang selalu menginginkan penampilan yang sempurna, terutama kaum wanita yang banyak menuntut kesempurnaan dan kecantikan. Bahkan saat ini bukan hanya wanita yang menginginkan penampilan sempurna, tetapi laki-laki juga mengikuti gaya hidup mulai dengan merawat kulit wajah. Perawatan kulit wajah saat ini sudah menjadi kebutuhan pokok bagi setiap orang untuk membuat mereka tampil lebih percaya diri dalam melakukan aktivitas sehari-hari.

Munculnya beragam kosmetik di pasaran tentu membuat kita sebagai pelanggan bingung untuk memilih. Namun saat ini banyak kosmetik yang beredar mengandung bahan berbahaya merkuri, dimana merkuri dapat merusak bagian tubuh manusia. Dari harga yang ditawarkan murah dan kualitas produk yang menjanjikan dengan hasil maksimal. Tentunya pelanggan pengguna produk kecantikan menginginkan kosmetik yang berkualitas dengan bahan yang herbal, natural, halal, dan tidak menimbulkan efek samping yang berbahaya.

Berdasar adanya permasalahan yang muncul mengenai kebutuhan kosmetik maka, PT. Natural Nusantara meluncurkan produk kosmetik terbuat dari bahan herbal, tidak mengandung merkuri, dapat digunakan dalam jangka panjang baik untuk ibu hamil atau menyusui. PT. Natural Nusantara merupakan sebuah perusahaan yang memiliki konsep produk terbuat dari bahan organik herbal dan merupakan hasil karya dari negeri sendiri bukan impor. Dalam menarik pelanggan maka perusahaan memberikan segala hal yang terbaik untuk meningkatkan loyalitas pelanggan. Produk kosmetik yang diluncurkan oleh PT. Natural Nusantara memiliki kualitas produk yang bagus, manfaat yang sesuai kebutuhan pelanggan, harga yang terjangkau dan merek yang selalu didengar lingkungan sekitar. Kosmetik Natural Nusantara yang dibuat dengan bahan herbal membuat konsumen semakin percaya akan produk tersebut. Setiap perusahaan penting dalam memperhatikan kualitas produk yang diproduksinya. Menurut Kotler dan Keller (2009), kualitas produk adalah totalitas fitur dan karakteristik produk atau jasa yang bergantung pada kemampuannya untuk memuaskan kebutuhan yang dinyatakan atau tersirat.

Selain kualitas produk harga mempunyai peran penting karena harga memainkan peran strategik dalam pemasaran. Bila harga terlalu mahal, maka produk bersangkutan bakal tidak terjangkau oleh pasar sasaran tertentu bahkan customer value menjadi rendah. Penetapan harga secara tepat merupakan faktor penting dalam menentukan kesuksesan dalam jangka pendek dan jangka panjang. Menurut Kotler (2009), harga adalah salah satu elemen bauran pemasaran yang menghasilkan pendapatan dan elemen lain menghasilkan biaya. Adapun menurut Grewal dan Levy (dalam Tjiptono, 2015), merumuskan definisi harga sebagai pengorbanan keseluruhan yang bersedia dilakukan konsumen dalam rangka mendapatkan produk atau jasa.

Faktor lain yang mempengaruhi loyalitas pelanggan yaitu citra merek. Citra merek padakosmetik Natural Nusantara sudah dikenal dengan positif dalam masyarakat, sehingga banyak yang menggunakan produk kosmetik dari Natural Nusantara dibandingkan dengan produk kosmetik lainnya. Pelanggan yang merasa puas dengan produk atau merek yang dikonsumsi maka akan melakukan pembelian ulang suatu produk dan menunjukkan loyalitas merek. Merek merupakan visualisasi dari citra yang ingin ditanamkan dibenak konsumen. Menurut Sudaryono (2016), brand image adalah citra yang dibangun dalam alam bawah sadar konsumen melalui informasi dan ekspektasi yang diharapkan melalui 
produk atau jasa. Citra merek dibangun dengan memasukkan kepribadian atau citra ke dalam produk atau jasa, untuk kemudian dimasukkan ke alam bawah sadar konsumen. Merek merupakan salah satu elemen penting dalam tema periklanan, untuk menunjukkan apa yang bisa diberikan oleh pemilik merek kepada pasar.

Persaingan yang begitu ketat menyebabkan perusahaan harus mampu memenuhi kebutuhan pelanggan agar dapat mempertahankan loyalitas pelanggan. Loyalitas mempunyai peran penting dalam perusahaan, mempertahankan pelanggan berarti mampu mempertahankan kelangsungan hidup produk dalam perusahaan. Loyalitas sebagai komitmen yang dipegang secara mendalam untuk membeli atau mendukung kembali produk atau jasa yang disukai di masa depan meski pengaruh situasi dan usaha pemasaran berpotensi menyebabkan pelanggan beralih. Menurut Morais (Sangadji dan Sopiah 2013), menyatakan bahwa loyalitas pelanggan adalah komitmen pelanggan terhadap suatu produk, atau pemasok, berdasarkan sifat yang sangat positif yang tercermin dalam pembelian ulang yang konsisten.

Penelitian tentang loyalitas pelanggan sebagai variabel dependen yang pernah dilakukan oleh Armiyyati dkk. (2013), menyatakan bahwa variabel kualitas produk tidak berpengaruh signifikan terhadap loyalitas pelanggan. Sedangkan berdasarkan Adawiah dkk. (2015), menyatakan harga dan citra merek secara parsial berpengaruh positif signifikan terhadap loyalitas pelanggan. Sedangkan berdasarkan Minawati (2017), harga dan kualitas produk secara parsial berpengaruh positif dan signifikan terhadap loyalitas pelanggan. Berbeda dengan Astri (2019), yang menyatakan kualitas produk berpengaruh signifikan terhadap loyalitas pelanggan dan harga tidak signifikan terhadap loyalitas pelanggan.
Penelitian bertujuan untuk mengetahui pengaruh Kualitas Produk, Harga, dan Citra Merek Terhadap Loyalitas Pelanggan" yang merupakan studi pada Pelanggan Pengguna Produk Kosmetik Natural Nusantara di Gunungkidul.

\section{Pengaruh Kualitas Produk terhadap Loy- alitas Pelanggan}

Menurut Kotler dan Keller (2009), produk adalah segala sesuatau yang dapat ditawarkan kepada pasar untuk memuaskan suatu keinginan atau kebutuhan, termasuk barang fisik, jasa, pengalaman, acara, orang, tempat, properti, organisasi, dan ide. Dalam mengembangkan sebuah produk mula-mula pemasar harus memilih tingkat kualitas. Tingkat kualitas yang tinggi berarti tingkat konsistensi tinggi. Tiga yang terkait erat dengan pengaruh kualitas yaitu: kualitas produk/jasa, kepuasan pelanggan, dan profitabilitas perusahaan. Semakin tinggi tingkat kualitas, semakin tinggi tingkat kepuasan pelanggan yang dihasilkan, yang mendukung harga lebih tinggi dan biaya yang lebih rendah. Kualitas mempunyai dampak langsung pada kinerja produk atau jasa. Menurut GE, John F. Welch Jr. (Kotler dan Keller, 2009), kualitas produk adalah jaminan terbaik atas loyalitas pelanggan hingga menjadi pertahanan terkuat menghadapi persaingan. Oleh karena itu, kualitas berhubungan erat dengan nilai dan kepuasan pelanggan. Melalui pemasaran dapat menarik dan mempertahankan pelanggan yang menguntungkan. Jika pelanggan merasa puas dengan kualitas produk maka akan merekomendasikan produk pada orang lain dan menggunakan secara terus menerus.

Penelitian terdahulu menurut Minawati, (2017) yang berjudul "pengaruh harga, kualitas produk dan kualitas pelayanan terhadap loyalitas pelanggan (studi kasus pelanggan Wardah di Universitas Muhammadiyah Surakarta)". Kualitas produk berpengaruh positif dan 
signifikan terhadap loyalitas pelanggan. Sedangkan penelitian yang dilakukan oleh Astri (2019), "daya tarik terhadap kosmetik emina". Kualitas produk berpengaruh positif dan signifikan terhadap loyalitas pelanggan. Berbeda dengan penelitian terdahulu menurut Amryyanti dkk. (2013), yang berjudul "pengaruh kualitas layanan, produk, dan kewajaran harga terhadap kepuasan dan loyalitas pelanggan pada LnC Skin Care Singaraja". Kualitas produk tidak berpengaruh signifikan terhadap loyalitas pelanggan. Berdasarkan teori dan penelitian terdahulu muncul hipotesis yaitu:

H1 : Kualitas produk berpengaruh positif dan signifikan terhadap loyalitas pelanggan pengguna produk kosmetik Natural Nusantara di Gunungkidul.

\section{Pengaruh Harga terhadap Loyalitas Pelanggan}

Produsen menetapkan harga pertama kali ketika menciptakan produk baru, memperkenalkan produk reguler ke saluran distribusinya atau ke daerah baru, atau ketika perusahaan membuat kontrak kerja baru. Menurut Kotler dan Keller (2009), harga adalah salah satu elemen bauran pemasaran yang menghasilkan pendapatan elemen lain menghasilkan biaya. Harga adalah elemen termudah dalam program pemasaran untuk disesuaikan; fitur produk, saluran, dan bahkan komunikasi membutuhkan lebih banyak waktu. Harga juga mengomunikasikan positioning nilai yang dimaksudkan dari produk atau merek perusahaan ke pasar. Produk yang dirancang dan dipasarkan dengan baik dapat dijual dengan harga tinggi dan menghasilkan laba yang besar. Harga memainkan peran strategik dalam pemasaran harga dapat menjadi senjata strategik untuk bersaing secara efektif. Menurut Tjiptono (2015), harga merupakan komponen yang berpengaruh langsung terhadap laba perusahaan. Sementara itu, dari sudut pandang konsumen harga seringkali digunakan sebagai indikator nilai bilamana harga tersebut dihubungkan dengan manfaat yang dirasakan atas suatu barang atau jasa. Nilai (value) dapat didefinisikan sebagai rasio antara manfaat yang dirasakan terhadap harga. Dengan demikian, dapat disimpulkan pada tingkat harga tertentu, bila manfaat dirasakan konsumen meningkat, maka nilainya meningkat. Demikian sebaliknya, pada tingkat harga tertentu, nilai suatu barang atau jasa akan meningkat seiring dengan meningkatnya manfaat hingga kepuasan yang di rasakan konsumen akan mendorong tercipta loyalitas pelanggan.

Penelitian terdahulu menurut Minawati (2017), yang berjudul "pengaruh harga, kualitas produk dan kualitas pelayanan terhadap loyalitas pelanggan (studi kasus pelanggan Wardah di Universitas Muhammadiyah Surakarta)". Harga berpengaruh positif dan signifikan terhadap loyalitas pelanggan. Sedangkan Penelitian terdahulu menurut Adawiah dkk. (2015), yang berjudul "pengaruh persepsi harga dan citra merek terhadap loyalitas pelanggan menggunakan produk kosmetik (studi pada swalayan grand hero di kota Palu)". Harga berpengaruh positif dan signifikan terhadap loyalitas pelanggan. Berbeda dengan penelitian yang dilakukan oleh Astri (2019), yang berjudul "daya tarik terhadap kosmetik emina". Harga tidak berpengaruh terhadap loyalitas pelanggan. Berdasarkan teori dan penelitian terdahulu muncul hipotesis yaitu:

H2 : Harga berpengaruh positif dan signifikan terhadap loyalitas pelanggan pengguna produk kosmetik Natural Nusantara di Gunungkidul.

\section{Pengaruh Citra Merek terhadap Loyalitas Pelanggan}

Menurut Simamora (Sangadji dan Sopiah, 2013), citra adalah konsep yang mudah dimengerti tetapi sulit dijelaskan secara sistematis karena sifatnya abstrak. Menurut Kotler dan Keller (2009), merek 
adalah produk atau jasa yang dimensinya mendiferensiasikan merek tersebut dengan beberapa cara dari produk atau jasa lainnya yang dirancang untuk memuaskan kebutuhan yang sama. Komponen citra merek Keller (Sangadji dan Sopiah, 2013), adalah jenisjenis asosiasi merek, dukungan, kekuatan, dan keunikan asosiasi merek.

Asosiasi merek asosiasi merupakan atribut yang ada di dalam merek dan akan lebih besar apabila pelanggan mempunyai banyak pengalaman berhubungan dengan merek tersebut. Berbagai asosiasi yang diingat oleh konsumen dapat dirangkai sehingga membentuk citra merek. Dukungan asosiasi merek merupakan respons konsumen terhadap atribut, manfat, serta keyakinan dari suatu merek produk berdasarkan penilaian merek atas produk. Atribut di sini tidak berkaitan dengan fungsi produk, tetapi berkaitan dengan citra merek. Kekuatan asosiasi merek setelah mengkonsumsi sebuah produk, konsumen akan mengingat kesan yang ditangkap dari produk tersebut. Jika konsumen telah merasakan manfatnya, ingatan konsumen terhadap produk tersebut akan lebih besar lagi dari pada ketika konsumen belum menggunakannya. Itulah yang membuat ingatan konsumen semakin kuat terhadap asosiasi sebuah merek. Kekuatan asosiasi merek ditunjukkan dengan reputasi baik yang dimiliki produk tersebut di mata konsumen, produk tersebut dirasa memiliki manfaat eksprsi diri dan menambah rasa percaya diri konsumen. Keunikan asosiasi merek jika sebuah produk mempunyai ciri khas yang membedakan dari produk lain, produk tersebut akan diingat oleh konsumen. Ingatan konsumen itu akan semakin kuat jika jika konsumen sudah merasakan manfaat dari sebuah produk dan merasakan bahwa merek lain tidak akan bisa memuaskan keinginan tersebut.

Apabila suatu produk atau jasa memiliki citra yang baik di masyarakat maka dapat memperoleh posisi yang baik, selalu dikosumsi atau digunakan oleh masyarakat. Citra merek merupakan pemahaman terhadap merek, kepercayaan terhadap merek, dan presepsi terhadap merek tersebut. Menurut Kotler dan Keller (2009), inti merek yang berhasil adalah produk atau jasa yang hebat, didukung oleh perencanaan yang seksama, sejumlah besar komitmen jangka panjang, dan pemasaran yang direncang atau dijalankan secara kreatif. Merek yang kuat menghasilkan loyalitas konsumen yang tinggi.

Penelitian terdahulu menurut Adawiah dkk. (2015) yang berjudul "pengaruh persepsi harga dan citra merek terhadap loyalitas pelanggan menggunakan produk kosmetik (studi pada swalayan grand hero di kota Palu)". Citra merek berpengaruh positif dan signifikan terhadap loyalitas pelanggan. Berdasarkan teori dan penelitian terdahulu muncul hipotesis yaitu:

H3: Citra merek berpengaruh positif dan signifikan terhadap loyalitas pelanggan pengguna produk kosmetik Natural Nusantara di Gunungkidul.

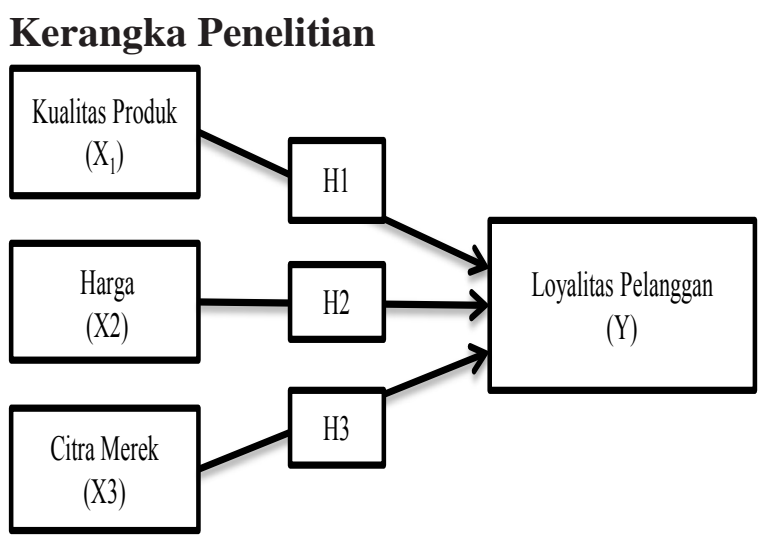

Gambar 1. Kerangka Penelitian

\section{METODE PENELITIAN}

Objek penelitian ini adalah kualitas produk, harga, citra merek, dan loyalitas pelanggan. Subjek penelitian ini pelanggan pengguna produk kosmetik Natural Nusantara 
di Gunungkidul. Populasi dalam penelitian ini adalah seluruh pelanggan pengguna kosmetik Natural Nusantara di Gunungkidul. Sampel dalam penelitian ini adalah sebagian pelanggan pengguna kosmetik Natural Nusantara di Gunungkidul. Menurut Roscoe (dalam Sugiyono, 2013), bila dalam penelitian akan melakukan analisis dengan multivariate (analisis regresi berganda), maka jumlah anggota sampel minimal sepuluh kali lebih besar dari jumlah variabel dalam penelitian. Berdasarkan pendapat tersebut maka peneliti menentukan jumlah minimal sampel sebanyak 40 responden, merupakan hasil dari perkalian jumlah variabel 4 (empat) di kali 10.

Dalam penelitian ini teknik pengambilan sampel dilakukan dengan menggunakan model Non-Probabilitas karena populasi dalam penelitian ini tidak diketahui. Metode yang digunakan adalah metode purposive sampling karena peneliti memilih sample berdasarkan penilaian terhadap beberapa karakteristik anggota sample yang disesuaikan dengan maksud penelitian. Kriteria pengampilan sampel dalam penelitian ini adalah sebagian pelanggan pengguna kosmetik Natural Nusantara di Gunungkidul, telah membeli produk kosmetik Natural Nusantara minimal dua kali pembelian.

\section{HASIL DAN PEMBAHASAN}

Pada penelitian ini data diperoleh dari penyebaran kuesioner kepada 102 responden untuk memberikan penilaian terhadap variabel-variabel yang diteliti yaitu kualitas produk, harga, citra merek dan loyalitas pelanggan. Sebanyak 102 kuesioner disebarkan kepada responden, ternyata terdapat 2 kuesioner yang tidak memenuhi syarat penelitian, sehingga hasil kuesioner yang dapat dikumpulkan sebanyak 100 kuesioner. Sehingga respons rate dalam penelitian ini adalah 98\%. Pembahasan dimulai dari karakteristik reponden, uji instrumen, uji asumsi dasar, uji asumsi klasik, uji hipotesis.

\section{Uji Instrumen}

Uji Validitas. Uji validitas dilakukan untuk mengukur valid atau tidak suatu kuesioner. Pengujian validitas pada penelitian ini dilakukan dengan menggunakan SPSS (Statistical Product and Service Solutions) 22.0 for Windows. Uji validitas dapat dilakukan dengan cara melihat korelasi antara skor pada masing-masing item dalam kuesioner dengan total skor yang akan diukur. Jika $\mathrm{r}$ hitung $\geq \mathrm{r}$ tabel, maka instrumen atau item-item pertanyaan berkorelasi signifikan terhadap skor total, maka dinyatakan valid. Jika $\mathrm{r}$ hitung $<\mathrm{r}$ tabel, maka instrumen atau item-item pertanyaan tidak berkorelasi signifikan terhadap skor total, maka dinyatakan tidak valid. Jumlah responden sebanyak 100 dan $r$ tabel 0,1966. Hasil uji validitas menunjukan bahwa dengan sample sebanyak 100 responden memiliki $\mathrm{r}$ hitung $\geq \mathrm{r}$ tabel $(0,1966)$ bernilai positif. Sehingga dapat disimpulkan bahwa item pernyataan masing-masing variabel dinyatakan valid dan dapat dijadikan sebagai instrumen penelitian.

Uji reliabilitas. Uji reliabilitas dalam penelitian ini dilakukan untuk mengukur suatu kuesioner yang merupakan indikator dari variabel. Dengan kata lain, keandalan suatu pengukuran merupakan indikasi mengenai stabilitas dan konsistensi dimana instrument mengukur konsep dan membantu menilai ketepatan sebuah pengukuran. Dengan menggunakan metode Cronbach's Alpha $>$ 0,600 dapat dikatakan bahwa instrumen yang digunakan sudah reliabel. Berdasarkan uji reliabilitas seluruh variabel memiliki nilai Cronbach's Alpha $>0,600$ sehingga dapat disimpulkan bahwa seluruh indikator pengukur variabel dari kuesioner adalah reliabel, yang artinya bahwa kuesioner yang digunakan dalam penelitian ini merupakan kuesioner yang handal. 


\section{Uji Asumsi Dasar}

Uji Normalitas, berguna untuk mengetahui apakah populasi data berdistribusi normal ataukah tidak. Dalam pembahasan persoalan normalitas ini akan digunakan uji one sample Kolmogorof-Smirnov dengan menggunakan taraf signifikansi 0,05. Datadata dapat dinyatakan berdistribusi normal jika signifikansi lebih besar dari 0,05 atau 5\%. Berdasarkan hasil uji normalitas yang dilakukan dengan menggunakan uji normalitas Kolmogorov-Smirnov nilai Asymp Sig. (2-tailed) tertinggi sebesar 0,200. Dari hasil Asymp Sig. (2-tailed) nilai signifikansi lebih dari 5\% (>0,050).

\section{Uji Asumsi Klasik}

Uji Multikolineritas. Digunakan untuk mengetahui ada atau tidaknya penyimpangan asumsi klasik multikolineritas yaitu adanya hubungan linier antar variabel independen dalam model regresi, model pengujian yang bisa digunakan yaitu dengan melihat nilai variance inflation factor (VIF). Jika VIF $>5$ maka ada multikolineritas dan VIF $<5$ maka tidak ada multikolineritas. Berdasarkan hasil uji multikolineritas nilai VIF ketiga variabel yaitu $<5$ maka tidak ada multikolineritas antar variabel dependen dalam model regresi.

Uji Heterokedastisitas. Untuk mengetahui ada atau tidaknya penyimpangan asumsi klasik heterokedastisitas yaitu adanya ketidaksamaan varian dari residual untuk semua pengamatan pada model regresi. Adapun kriteria pengujian sebagai berikut. Jika -ttabel $\leq$ thitung $\leq$ ttabel, yang berarti tidak terdapat heterokedastisitas. Jika thitung $>$ ttabel atau -thitung $<$-ttabel, yang berarti terdapat heterokedastisitas. Berdasarkan hasil uji heterokedastisitas $\mathrm{t}$ hitung $-1,202$, $-1,957$ dan $-0,785$. Dengan t tabel $\mathrm{df}=\mathrm{n}-2$ atau $100-2=98$ adalah sebesar 1,98447 .

Kualitas produk $-1,98447 \leq-1,202 \leq$ 1,98447 maka Ho diterima artinya tidak ada gejala heterokedastisitas.

Harga $-1,98447 \leq-1,957 \leq 1,98447$ maka Ho diterima artinya tidak ada gejala heterokedastisitas.

Citra merek $-1,98447 \leq-0,785 \leq 1,98447$ maka Ho diterima artinya tidak ada gejala heterokedastisitas.

\section{Analisis Regresi Linier Berganda}

Dalam penelitian ini menggunakan analisis regresi linier berganda tujuannya adalah untuk membuktikan hipotesis mengenai pengaruh variabel independen secara parsial maupun secara bersamasama terhadap variabel dependen. Hasil pengolahan data sebagai berikut.

Tabel 1. Hasil Analisis Regresi Linear Berganda

\begin{tabular}{|c|c|c|c|c|c|c|}
\hline & \multirow{2}{*}{ Model } & \multicolumn{2}{|c|}{$\begin{array}{c}\text { Unstandardized } \\
\text { Coefficients }\end{array}$} & \multirow{2}{*}{$\begin{array}{c}\text { Standardized } \\
\text { Coefficients } \\
\text { Beta }\end{array}$} & \multirow[b]{2}{*}{$\mathrm{T}$} & \multirow[b]{2}{*}{ Sig. } \\
\hline & & $\mathrm{B}$ & Std. Error & & & \\
\hline \multirow[t]{4}{*}{1} & (Constant) & 15.163 & 4.076 & & 3.720 & .000 \\
\hline & Kualitas Produk & .212 & .093 & .221 & 2.276 & .025 \\
\hline & Harga & .433 & .098 & .429 & 4.424 & .000 \\
\hline & Citra merek & -.006 & .081 & -.006 & -.069 & .945 \\
\hline
\end{tabular}

Sumber: Data primer diolah SPSS 22.0, 2019. 
Interpretasi berdasarkan persamaan tersebut dapat diartikan sebagai berikut:

a. Nilai konstanta sebesar 15,163. Jika kualitas produk, harga dan citra merek sama dengan nol, maka loyalitas pelanggan sebesar 15,163 .

b. Koefisien regresi kualitas produk (X1) sebesar $+0,212$. Hal ini menunjukan bahwa kualitas produk mempunyai hubungan yang searah. Artinya jika kualitas produk meningkat, maka loyalitas pelanggan meningkat.

c. Koefisien regresi harga (X2) sebesar + 0,433 . Hal ini menunjukan bahwa harga mempunyai hubungan yang searah. Artinya jika harga meningkat, maka loyalitas pelanggan meningkat.

d. Koefisien regresi citra merek (X3) sebesar -0,006. Hal ini menunjukan bahwa citra merek mempunyai hubungan yang berlawanan arah. Artinya jika citra merek menurun, maka loyalitas pelanggan akan meningkat.

\section{Uji Hipotesis}

Uji t. Uji statistik t pada dasarnya menunjukan seberapa jauh pengaruh satu variabel penjelas/independen secara individual dalam menerangkan variasi variabel terikat/dependen.

1. Jika $\mathrm{t}$ hitung $>\mathrm{t}$ tabel, dengan taraf signifikansi lebih kecil dari 0,05 maka $\mathrm{H} 1, \mathrm{H} 2, \mathrm{H} 3$, diterima.

2. Jika $\mathrm{t}$ hitung $\leq \mathrm{t}$ tabel, dengan taraf signifikansi lebih besar dari 0,05 maka $\mathrm{H} 1, \mathrm{H} 2, \mathrm{H} 3$, ditolak.

Hasil pengolahan data dengan menggunakan program SPSS 22.0 sebagai berikut.
Tabel 2. Uji t

\begin{tabular}{lcrc}
\hline \multicolumn{1}{c}{ Model } & $\mathrm{t}$ tabel & $\mathrm{t}$ hitung & \multicolumn{1}{c}{ Sig. } \\
\hline Constant) & & 3.720 & .000 \\
Kualitas Produk & 1.98447 & 2.276 & .025 \\
Harga & 1.98447 & 4.424 & .000 \\
Citra merek & 1.98447 & -.069 & .945 \\
\hline
\end{tabular}

Sumber: Data primer diolah SPSS 22.0, 2019

Berdasarkan Tabel 2, berikut adalah hasil penjelasan mengenai pengaruh antar variabel kualitas produk, harga dan citra merek terhadap loyalitas pelanggan. Variabel kualitas produk dengan nilai t hitung sebesar $2,276>\mathrm{t}$ tabel sebesar 1,98447 atau nilai sig. lebih kecil dari 0,05 $(0,025<0,05)$, maka dapat disimpulkan kualitas produk berpengaruh signifikan terhadap loyalitas pelanggan pengguna produk kosmetik Natural Nusantara di Gunungkidul. H1 diterima.

Variabel harga dengan nilai t hitung sebesar 4,424 > t tabel sebesar 1,98447 atau nilai sig. lebih kecil dari $0,05(0,000<0,05)$, maka dapat disimpulkan harga berpengaruh signifikan terhadap loyalitas pelanggan pengguna produk kosmetik Natural Nusantara di Gunungkidul. H2 diterima.

Variabel citra merek dengan nilai $\mathrm{t}$ hitung sebesar $-0,069 \leq \mathrm{t}$ tabel 1,98447 atau nilai sig. lebih besar dari $0,05(0,945 \geq$ 0,05), maka dapat disimpulkan citra merek tidak signifikan terhadap loyalitas pelanggan pengguna produk kosmetik Natural Nusantara di Gunungkidul. H3 ditolak.

\section{Koefisien Determinasi (Adjusted} R2). Koefisien determinasi digunakan untuk mengukur seberapa jauh kemampuan model dalam menerangkan variasi variabel dependen. Hasil koefisien determinasi dapat dilihat pada Tabel 3: 
Tabel 3. Hasil Uji Koefisien Determinasi (Adjusted R2)

\begin{tabular}{ccccc}
\hline Model & $\mathrm{R}$ & $\begin{array}{c}\mathrm{R} \\
\text { Square }\end{array}$ & $\begin{array}{c}\text { Adjusted } \\
\text { R Square }\end{array}$ & $\begin{array}{c}\text { Std. Error } \\
\text { of the } \\
\text { Estimate }\end{array}$ \\
\hline 1 & $.574 \mathrm{a}$ & .329 & .308 & 2.243 \\
\hline
\end{tabular}

Sumber: Data primer diolah SPSS 22.0, 2019

Berdasarkan Tabel 3 diperoleh Adjusted R2 sebesar 0,308 hal ini menunjukan bahwa sumbangan variabel kualitas produk, harga dan citra merek terhadap loyalitas pelanggan sebesar 0,308 atau 30,8\% sedangkan sisanya sebesar $69,2 \%$ yang tidak dijelaskan dalam penelitian ini.

\section{Hasil Analisis Kualitas Produk}

Dengan hasil pengujian hipotesis kualitas produk dengan taraf signifikansi $0,025<0,05$, yang berarti bahwa hipotesis dalam penelitian ini kualitas produk berpengaruh positif dan signifikan terhadap loyalitas pelanggan, sehingga $\mathrm{H} 1$ diterima. Berdasarkan analisis di atas, penelitian ini mempunyai hasil yang sama dengan penelitian Astri (2019), yang menyatakan kualitas produk berpengaruh positif dan signifikan terhadap loyalitas pelanggan. Produk kosmetik natural nusantara yang dikeluarkan sesuai dengan kebutuhan dan keinginan pelanggan. Sehingga, pelanggan akan merasa puas dan merekomendasikan produk kosmetik Natural Nusantara pada orang lain hingga menggunakan produk kosmetik Natural Nusantara secara terus menerus.

\section{Hasil Analisis Harga}

Dengan hasil pengujian hipotesis harga dengan taraf signifikansi $0,000<0,05$, yang berarti bahwa hipotesis dalam penelitian ini harga berpengaruh positif dan signifikan terhadap loyalitas pelanggan, sehingga $\mathrm{H} 2$ diterima. Berdasarkan analisis di atas hasil yang sama dengan penelitian Adawiah dkk. (2015), harga berpengaruh positif dan signifikan terhadap loyalitas pelanggan. Harga merupakan faktor terpenting bagi pelanggan saat memilih produk kosmetik Natural Nusantara dan harga mempunyai peran penting dalam meningkatkan loyalitas pelanggan. Dengan demikian, jika harga produk kosmetik natural nusantara sesuai dengan manfaat yang dirasakan pelanggan meningkat, maka nilainya akan meningkat.

\section{Hasil Analisis Citra Merek}

Dengan hasil pengujian hipotesis citra merek dengan taraf signifikansi 0,945 $\geq$ 0,05 , yang berarti bahwa hipotesis dalam penelitian ini citra merek tidak berpengaruh signifikan terhadap loyalitas pelanggan. Berlawanan dengan penelitian Adawiah dkk. (2015), citra merek berpengaruh positif dan signifikan terhadap loyalitas pelanggan. Citra merek merupakan sekumpulan asosiasi merek yang terbentuk di benak konsumen. Namun citra merek yang ada pada produk kosmetik Natural Nusantara tidak mempengaruhi loyalitas pelanggan. Dengan demikian citra merek yang ada pada produk kosmetik Natural Nusantara mudah diingat, mudah diucapkan, mudah dikenali belum cukup untuk menimbulkan loyalitas pelanggan.

\section{SIMPULAN DAN SARAN}

Berdasarkan data yang diperoleh dari hasil analisis, maka dapat ditarik beberapa kesimpulan sebagai berikut:

1. Kualitas produk berpengaruh positif dan signifikan terhadap loyalitas pelanggan pengguna produk Kosmetik Natural Nusantara di Gunungkidul.

2. Harga berpengaruh positif dan signifikan terhadap loyalitas pelanggan pengguna produk Kosmetik Natural Nusantara di Gunungkidul.

3. Citra merek berpengaruh negatif dan tidak signifikan terhadap loyalitas 
pelanggan pengguna produk Kosmetik

Natural Nusantara di Gunungkidul.

Dari hasil kesimpulan yang telah diuraikan, maka saran-saran yang dapat diberikan sebagai berikut:

1. Dari hasil analisis, variabel citra merek berpengaruh negatif dan tidak signifikan terhadap loyalitas pelanggan. Dalam hal ini pihak PT. Natural Nusantara khususnya peluncuran produk kosmetik diharapkan dapat meningkatkan promosi karena dalam penelitian ini citra merek tidak memiliki pengaruh terhadap loyalitas pelanggan. Dari segi kualitas produk dan harga sudah berpengaruh positif dan signifikan terhadap loyalitas pelanggan maka PT. Natural Nusantara agar dapat mempertahankan atau meningkatkan kualitas produk dan menetapkan harga sesuai dengan manfaat yang diharapkan atau menetapkan harga sesuai dengan pendapatan pelanggan, sehingga loyalitas pelanggan akan terjaga dan meningkat.

2. Dengan adanya hasil penelitian yang berbeda dengan penelitian lainnya, maka penelitian ini bisa menjadi gap bagi peneliti selanjutnya.

\section{REFERENSI}

Adawiah, R., dkk. (2015). Pengaruh Persepsi Harga Dan Citra Merek Terhadap Loyalitas Pelanggan Menggunakan Produk Kosmetik. Jurnal Ilmu Manajemen Universitas Tadulako, 1(3), 271-278.

Astri, N. S. A., \& Saputro, E. P. (2019). Daya Tarik Terhadap Kosmetik Merek Emina (Disertasi doktor, Universitas Muhammadiyah Surakarta).

Gadau, M. (2016). Pengaruh Citra Merek (Brand Image) terhadap Loyalitas Konsumen. Skripsi Fakultas
Ekonomi Universitas Sanata Dharma Yogyakarta.

Kotler, Philip dan Keller, Kevin L. (2009). Manajemen Pemasaran. Jilid 1. Edisi 13. Jakarta: Erlangga.

Kotler, Philip dan Keller, Kevin L. (2009). Manajemen Pemasaran. Jilid 2. Edisi 13. Jakarta: Erlangga.

Lestari, Ani dan Yulianto, Edy. (2018). Pengaruh Kualitas Produk Terhadap Loyalitas Pelanggan dengan Kepuasan sebagai Variabel Mediasi (Survai Pada Pelanggan Citra Kendedes Cake \& Bakery Jl. S. Hatta B3 Kav. A, Kota Malang. Jurnal Administrasi Bisnis Universitas Brawijaya, 54(1), 74-81.

PT. Natural Nusantara. (2017). Katalog Produk Natural Nusantara, 1: 1-106.

Sangadji, Etta Mamang dan Sopiah. (2013). Perilaku Konsumen-Pendekatan Praktis Disertai Himpunan Jurnal Penelitian. Yogyakarta: Andi.

Sudaryono. (2016). Manajemen Pemasaran Teori dan Implementasi. Yogyakarta: Andi.

Sugiyono. (2013). Metode Penelitian Manajemen. Bandung: Alfabeta.

Tjiptono, Fandy. (2015). Strategi Pemasaran. Edisi 4. Yogyakarta : Andi.

Wasiman. (2017). Pengaruh Citra Merek, Harga Dan Kualitas Pelayanan Terhadap Loyalitas Konsumen Pada Perusahaan Property Di Kota Batam. JIM UPB: Jurnal Ilmiah Manajemen Universitas Putera Batam, 5(2), 122129. 